\title{
DOCUMENTOS SOBRE JERÓNIMO DE CÁNCER Y VELASCO*
}

\author{
ELENA MARTÍNEZ CARRO \\ ALEJANDRO RUBIO SAN ROMÁN
}

\begin{abstract}
Estos libros sólo es posible escribirlos con materiales viejos y absurdos, aunque eso también les proporciona, me parece a mí, una perspectiva interesante la de dar entrada a lo menor, a lo que solemos llamar "lo menor", no siempre menor. ${ }^{1}$
\end{abstract}

En las últimas décadas, estudiosos y críticos de la literatura española vienen prestando atención a la obra de Jerónimo de Cáncer y Velasco. Las investigaciones sobre este Ingenio del siglo XVII se han dirigido, primordialmente, a su obra dramática y poética, como lo avalan las recientes publicaciones sobre sus comedias². Sin embargo no tienen la misma fortuna las

* Agradecemos la colaboración que nos han prestado los sacerdotes de la Iglesia de San Sebastián de Madrid, así como el personal del Archivo de Protocolos, para llevar a cabo este artículo.

1 A. Trapiello, Los nietos del Cid, La nueva edad de oro de la literatura española (1898-1914), Barcelona, Planeta, 1997, p. 12.

2 Un repaso de la bibliografía más reciente -que muestra el estado actual de los estudios sobre Jerónimo de Cáncer-, se ha centrado en la edición y análisis de sus comedias burlescas, por ser éstas las que más fama dieron al poeta. Vid. L. García Lorenzo, «La comedia burlesca en el siglo XVII. Las mocedades del Cid de Jerónimo de Cáncer», Segismundo, 25-26 (1977), pp. 131-146; C. Mata Induráin, «Cáncer y la comedia burlesca», en Historia del Teatro Español, Madrid, Gredos, 2003, pp. 1069-1096; P. Micozzi, «Juan Vélez de Guevara-Jerónimo de Cáncer: Los siete infantes de Lara (fiesta 
aportaciones e investigaciones sobre su vida, pues son muy escasas las referencias documentales que han llegado hasta nosotros.

La actual información biográfica es la que antaño sacaron a la luz Latassa $^{3}$, La Barrera ${ }^{4}$, Gallardo5, Pérez Pastor6, Cotarelo y Mori , recogida en los

que en 1650 se representó a Su Majestad del rey Felipe IV)», en Actas del X Congreso Internacional de Hispanistas (1992), Barcelona, pp. 1033-1004; N. Pérez García, «Lope de Vega, Jerónimo de Cáncer y las dramatizaciones áureas de los romances del marqués de Mantua», Cuadernos para la Investigación de la Literatura Hispánica, 26 (2001), pp. 189-205; M.L. Reverdito, «La comicitá verbale negli “entremeses" di Cáncer y Velasco», Letterature (1990), 13, pp. 42-52; A. Rodríguez Rípolas, Comedias burlescas del Siglo de Oro, tomo IV: Las mocedades del Cid, El castigo en la arrogancia, El desdén con el desdén, El premio de la hermosura, Madrid-Pamplona, Iberoamericana-Universidad de Navarra, 2003; Seminario de Estudios Teatrales, «Edición de una comedia burlesca del siglo XVII: Las mocedades del Cid de Jerónimo de Cáncer», Cuadernos para la Investigación de la Literatura Hispánica, 23 (1998), pp. 243-297; Seminario de Estudios Teatrales, La comedia burlesca del siglo XVII: La muerte de Valdovinos, de Jerónimo de Cáncer (Edición y estudio), Cuadernos para la Investigación de la Literatura Hispánica, 25 (2000), pp. 101-164; P. Taravacci (ed.), Jerónimo de Cáncer y Juan Vélez de Guevara, Los siete infantes de Lara, Luca, Mauro Baroni, 1999.

3 Una de las primeras noticias biográficas corresponde a Latassa; es posible que, a partir de esta transcripción, la tomen como autoridad los críticos y estudiosos posteriores sin cuestionarse nada sobre Cáncer: “Nació en Barbastro a fines del siglo XVI. El estado familiar, que tuvo en la casa del Conde de Luna, fue causa de que le manifestase su gratitud, como lo manifiestan varios poemas suyos, que desde su juventud compuso con mucha gracia. En efecto, la urbanidad, elegancia, dulzura y agudeza en que abundan sus versos, le dan un mérito agradable. Murió en Madrid en el Setiembre de 1655, habiendo escrito:

$1^{\circ}$ - Poesías varias, que recogidas en un tomo llevan el título de: Obras varias de D. Gerónimo Cáncer. Dedicadas al Duque de Medina Sidonia. Madrid, 1651, por Diego Díaz de la Cámara. 2Diferentes comedias publicadas en diversos tiempos.

$3^{\circ}$ - Otros versos sueltos." Vid. Bibliotecas de Latassa, edición electrónica a cargo de Manuel José Pedraza García, José Ángel Sánchez Ibáñez y Luis Julve Larranz, Zaragoza, 2001.

${ }^{4}$ C.A de La Barrera y Leirado, Catálogo bibliográfico del teatro antiguo español, desde los orígenes hasta mediados del siglo XVII, Madrid, Imp. M. Rivadeneira, 1860, pp. 62-64.

${ }^{5}$ B.J. Gallardo, Ensayo de una biblioteca española de libros raros y curiosos, Madrid, Imp. Rivadeneyra, 1863-1889. II, pp. 211-212.

${ }^{6}$ C. Pérez Pastor, Noticias y Documentos Relativos a la Historia y Literatura Españolas, Madrid, Imprenta de la Legislación, 1910, I, p. 72.

${ }^{7}$ Los estudios de Cotarelo impulsaron el interés por el teatro del siglo XVII, como demuestran las monografías que publicó en las primeras décadas del siglo XX. Vid. E. Cotarelo y Mori, Colección de entremeses, loas, bailes y mojigangas desde finales del siglo XVI a mediados del siglo XVIII, Madrid, Editorial Bailly-Bailliére, 1911, p. LXXXIV.

Posteriormente otros estudiosos también presentaron atención a su obra teatral, como el caso de Cañedo Fernández, cuando reedita en la "Biblioteca de Antiguos Libros Hispánicos", dirigida por J. de Entramabasaguas, el Vergel de entremeses, en esta colección se incluye dos entremeses de Cáncer: Entremés del negro hablador y Entremés de la visita a la cárcel. Vid. J. Cañedo Fernández, Vergel de entremeses, Madrid, C.S.I.C., 1970, pp. 107-119. También Hannah E. Bergman publica el Ramillete de entremeses y bailes..., en donde recoge varias obras de Cáncer: El cortesano, La visita a la cárcel, Los hombres deslucidos. Vid. H.E. Bergman, Ramillete de entremeses y bailes nuevamente recogido de los antiguos poetas de España. Siglo XVII, Madrid, Castalia, 1970, pp. 279-289 y pp. 301-322. 
manuales de historia de la literatura, diccionarios y enciclopedias, que entre sus contenidos incluyen reseñas sobre escritores y obras. A su vez, algunas composiciones poéticas -generalmente las más jocosas y llamativas- se han recogido en diversas antologías, y se han repetido -en ocasiones- sin atender a sus fuentes. ${ }^{8}$

Recientemente, Solera López ha editado las Obras varias de Cáncer ${ }^{9}$. En su introducción incluye un "estudio biográfico", en el que resume y recopila la información conocida -hasta el momento- sobre la vida del dramaturgo, pero todo parece indicar, que poco o nada, se ha avanzado en las aportaciones documentales sobre la biografía de Cáncer.

El poeta tuvo fama de relatar sus penurias -más que fortunas- en poesías y vejámenes. Al hilo de sus composiciones, puede verse la ridiculización jocosa que hace de sí mismo y de sus enfermedades, como si de una broma se tratara:

Mas pasando a mi persona, soy tan chico y tan retaco, que yo mismo no me llego a la barba con un palmo.

Como una endrina soy negro, $\mathrm{y}$ mil veces he pensado que en vez de materia prima, con campeche me engendraron. ${ }^{10}$

Clori, mal convaleciente, quiere el amor que os escriba los tartamudos efectos de mi torpe perlesía. Ya habréis oído decir que esta boca maligna, antes de cumplir el tercio

\footnotetext{
${ }^{8}$ Entre las antologías destacan las recogidas por A. de Castro de carácter jocoso, como la sátira "Que haya novio tan honrado", "Enderezaos Lucía", "Décima a un hombre muy rico, que a nadie quitaba el sombrero" y, la última, que recoge este antólogo, corresponde "A un amigo suyo que le envió un barril de aceitunas muy malas". Vid. A. de Castro, Poetas líricos de los siglos XVI y XVII, Madrid, Rivadeneira, 1857, pp. 161-162.

Entre otras antologías caben destacar J.M. Blecua, La poesía aragonesa del barroco, Zaragoza, Guara, 1986, pp. 151-155; I. Arellano y V. Roncero, Poesía satírica y burlesca de los Siglos de Oro, Madrid, Espasa Calpe, 2002, pp. 321-326.

9 J. Cáncer y Velasco, Obras varias, edición, introducción y notas de R. Solera López, Zaragoza, Prensas Universitarias de Zaragoza, 2005, pp. XI-XXXII.

${ }^{10}$ Citamos los versos de Obras Varias de Cáncer según la edición mencionada de Rus Solera. «A una dama que tenía deseo de conocer al poeta pintándose. Andaba entonces vestido de estudiante», Obras Varias, vv. 33-40, p. 202.
} 
se me mudó a una mejilla.

No sé que enfado la hice,

que se me puso torcida

y dos dedos del oído

me dijo lo que sentía. ${ }^{11}$

No queda atrás el relato de las adversidades sin cuento, de la tacañería de sus señores y de las "infinitas" necesidades que pasaba junto a su familia.

Sucede el mediodía a la mañana

y mi familia, en fin come gustosa

hasta cubrir la línea de la gana.

Entra la tarde y fáltame una cosa:

quiso Dios que el maná sólo durase

un día, y fue cautela misteriosa

porque su pueblo de él no se olvidase.

Pero en mí echa más cortos los niveles,

que porque sin pedille nunca pase,

se acaba mi maná con los manteles. ${ }^{12}$

\author{
Mi familia los más días \\ se suele pasar con versos, \\ y mi mujer dice a todos \\ que come platos compuestos. \\ Mi vestido es tan mañoso, \\ que sabe engañar al tiempo, \\ y el tafetán del verano \\ da el nombre y pasa el invierno. \\ Si el alquiler de mi casa \\ pago, destruido quedo. \\ Mas, ¿qué mucho que lo quede \\ Si de mí ha salido un tercio? ${ }^{13}$
}

11 «Habiendo estado el poeta enfermo de perlesía, de comer lamprea», Obras varias, vv. 1-12, p. 223.

12 «Carta a un amigo suyo, que le encargó que asistiese a una dama que había dejado en Madrid», Obras varias, vv. 121-130, p. 237.

13 «Al Rey Nuestro Señor, pidiéndole una ayuda de costa, habiendo representado el poeta en la comedia que hicieron los criados de su majestad», Obras varias., vv. 37-48, p. 33. 
Estos versos exentos y otros muchos -escritos con evidente sarcasmo-, han creado una imagen novelada del poeta -de su físico, de su familia, penurias y malas fortunas-, sin base documental alguna. En la mayoría de los casos, puede decirse que la imagen forjada por su literatura ha alejado a Cáncer de la realidad personal, a veces contradictoria, que proyecta en nuestros días.

Siempre ha existido el riesgo de confundir aspectos biográficos de los escritores con determinados contenidos o informaciones de su obra, cuyos presuntos equívocos no son otros que la falta de documentos conservados en archivos, y que -aún hoy- no se han expurgado adecuadamente. De ahí la necesidad de seguir buscando fuentes documentales que abran nuevos caminos de estudio para la interpretación de su producción literaria.

Es nuestro propósito aclarar algunos hechos acerca de la vida de Cáncer, mediante la publicación de ciertos documentos inéditos sobre su biografía, que tienen trascendencia en su obra.

No sabemos exactamente en qué momento Cáncer se estableció en Madrid, pero el primer documento que conocemos y que le vincula a la Corte, data del día tres noviembre de 1625, en el que se comunica su matrimonio con doña María de Ormaza en la Parroquia de San Sebastián, como lo atestigua el documento de amonestaciones que incluye Cotarelo, en la introducción de Colección de entremeses...:

Don Gerónimo de Cáncer y Velasco con Doña María de Ormaza Amonestaciones: I en I; 2 en 2; Der. 9 de noviembre.- En tres de noviembre de 1625 años, con mandamiento del Sr. D. Juan Mendieta, vicario general de esta Villa de Madrid y su partido, que pasó ante Simón Ximénez, su notario, su fecha en este día, mes y año, no obstante que no están hechas más que dos amonestaciones de las que el Santo Oficio manda, yo, el Licenciado, Francisco de Corbalán, teniente cura de esta iglesia parrochial de San Sebastián de esta villa de Madrid, despose in facie ecclesiae, por palabras de presente y con su mutuo consentimiento a D. Jerónimo de Velasco y Cáncer con Doña María de Ormaza, por cuanto su merced del dicho señor Vicario dispensó en la amonestación que falta y la notifiqué no velen ni cohabiten hasta estar hecha la amonestación que falta. Testigos: D. Luis de Guzmán y fray Leonardo Rojas de la Santísima Trinidad, Francisco de Ancejo y otros, y lo firmé. Fecha ut supra.- El L[icencia]do. Francisco Corbalán." (Tomo de matrimonio de dicho año; folio 81 vuelto). ${ }^{14}$

14 E. Cotarelo y Mori, Colección de entremeses, op. cit., p. LXXXIV. Este documento no se encuentra en los libros donde se registraban las partidas de bautismo, sino en el Libro de Matrimonios, rectificamos así la errata de Cotarelo, que posiblemente tomó de Pérez Pastor. 


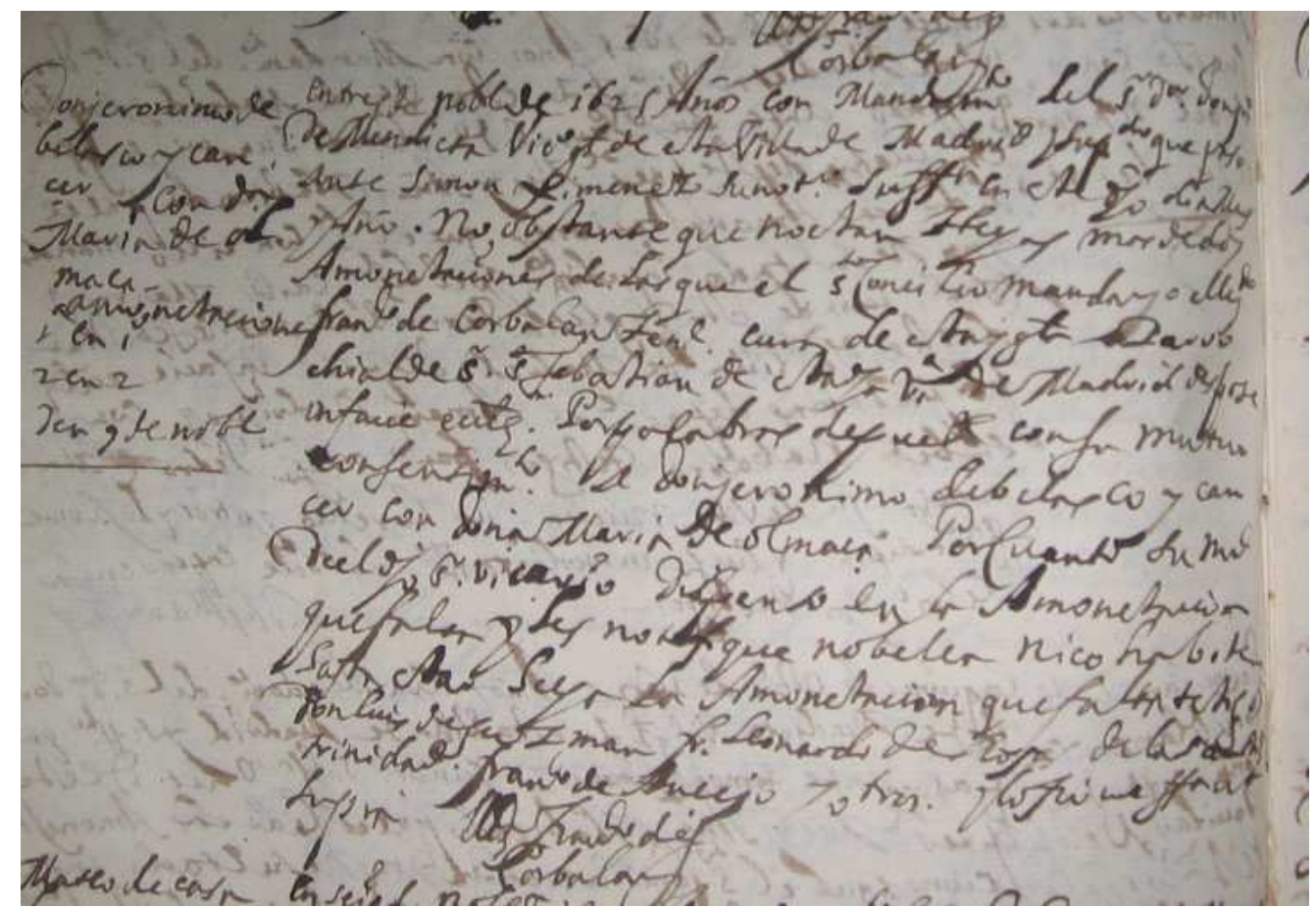

Sobre la descendencia del matrimonio entre Jerónimo de Cáncer y María Ormaza dio noticia Cotarelo y Mori ${ }^{15}$ en su Colección de entremeses..., donde publicó la partida de bautismo de Polonia, cuya datación corresponde al día veinte y seis de febrero de 1634, en la iglesia de San Sebastián. Hasta la fecha, de esta nuestra publicación, se la ha considerado como la única hija del matrimonio, y algunos críticos y estudiosos sobre la vida y obra de Cáncer, se han recreado en teorías peregrinas, como la de Sainz de Robles, de la que nos da cumplida cuenta Solera López ${ }^{16}$, basándose en textos pretendidamente autobiográficos del poeta:

Hasta acostarme, paso entretenido a mi hija celebrándole algún chiste, de mi mujer contado y añadido. ${ }^{17}$

15 E. Cotarelo y Mori, Colección de entremeses, op. cit., p. LXXXIV.

16 J. Cáncer y Velasco, Obras varias, op. cit., p. XX

17 «Carta a un amigo suyo que le encargó que le asistiese a una dama que había dejado en Madrid», Obras varias, vv. 106-108, p. 236. 

familia ${ }^{18}$ :

Y contradictorios con otras alusiones que el mismo Cáncer hace sobre su

¿No está cansado de ser pobre? ¿Por qué no acaba de ser secretario, pues Dios le dio entendimiento? ¿Viénesele la fortuna a casa y no la quiere? ¿No ve que tiene hijos para quien sea? ¿Por qué no acaba de aplicarse? ¡Qué su flojedad nos tiene en el estado en que estamos! ¿Es mejor andarse haciendo coplitas? ${ }^{19}$

Desconocían -por tanto- que en esta misma parroquia se conservan las partidas de bautismo de otras dos hijas: Ana, que se cristianizó el catorce de octubre de 1627 y María que tomó las aguas bautismales el trece de marzo de 1631. Las partidas de bautismo de estas dos niñas son los únicos documentos que conocemos de ellas hasta ahora. También existe una tercera hija, Antonia, cuya partida de bautismo data del seis de mayo de 1632 y que será la única hija incluida en el testamento de doña María Ormaza, su madre.

Nuestra investigación se ha centrado en el Archivo de la Parroquia de San Sebastián, entre cuyos documentos existen una serie de ellos, que están relacionados directamente con don Jerónimo de Cáncer y Velasco. Estos revelan la existencia de una numerosa descendencia dentro de su matrimonio con María de Ormaza, así como una nómina de personajes que tienen interés en la vida del poeta, que a continuación, reproducimos, transcribimos, modernizamos y ordenamos cronológicamente.

De sus hijos sólo hemos encontrados las partidas de bautismo que, por su indudable interés, reproducimos íntegramente. Todos nacieron en Madrid y fueron bautizados en la Parroquia de San Sebastián. Entre las informaciones de interés que poseen estas partidas figuran los nombres de los padrinos, cuya identidad no hemos podido identificar en la mayoría de los casos, así como las casas en las que Cáncer vivió. La mayoría, o si no todas, sospechamos que fueron de alquiler. Ubicadas en distintas calles: Atocha, Santa María, Las Huertas, del Prado..., fueron el hogar de los Cáncer durante poco tiempo, a juzgar por los años señalados en las partidas de Bautismo.

Su primer hijo fue Jerónimo, que nació en Madrid, el día 9 de septiembre de 1626, en la calle Atocha, en la casa donde vivían, que hasta el momento no ha sido identificada.

La partida de bautismo nos informa: “En la Iglesia Parroquial de San

\footnotetext{
18 A esta "contradicción" hacía referencia Rus Solera en su trabajo, sin embargo, aseguraba refiriéndose a la posible descendencia del poeta: "No se han encontrado registros documentales que certifiquen la existencia de más descendencia", Obras varias, op. cit., p. XX. 19 «Vejamen que dio siendo secretario de la academia», Obras varias., p. 152.
} 
Sebastián de esta Villa de Madrid, en dos de octubre de 1626 años, yo, Carlos Manrique, teniente cura de dicha Iglesia, bauticé a Jerónimo, que nació el nueve de septiembre, hijo de don Jerónimo de Cáncer y doña María de Ormaza, su legítima mujer, que viven en la calle Atocha, Y fueron sus padrinos don Antonio Álvarez de Boorques ${ }^{20}$ y doña Ana Centeno. Firmado Carlos Manrique" 21.

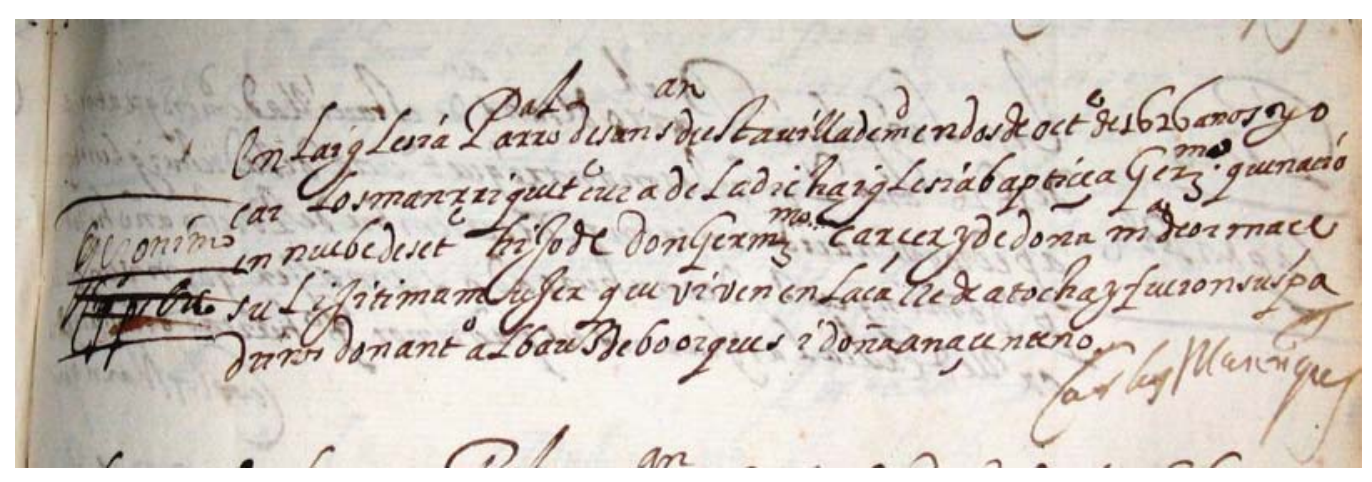

En el año 1627, nace su primera hija, Ana, como lo atestigua la partida de bautismo: "En la Iglesia Parroquial de San Sebastián de esta Villa de Madrid, en catorce de octubre de 1627 años; yo, Carlos Manrique, teniente cura de dicha Iglesia, bauticé a Ana, que nació el veinte y seis de setiembre del dicho año, hija de don Jerónimo Cáncer de Velasco y de doña María de Ormaza, su mujer legítima; que viven en la calle Atocha. Fueron sus padrinos don Luis de Guzmán $^{22}$ y doña Magdalena de Sosa. Firmado Carlos Manrique" 23.

20 En el Archivo del Palacio Real de Madrid, en el expediente Caja 43/14 aparece el nombre de Álvarez Boorques como "paje de su Majestad", posiblemente fue amigo de la familia.

${ }^{21}$ Archivo de la Parroquia de San Sebastián, Lib. 9 Baut. Fol.163. Vid, M. Fernández García, Parroquia madrileña de San Sebastián, Madrid, Caparrós, 1995, p. 30.

${ }^{22}$ La Barrera cita en su Catálogo, a "Don Luis de Guzmán como autor de comedias como "El blasón de don Ramiro, y libertad del fuero de las cien Doncellas. (Parte 2. ${ }^{a}$ de Madrid, 1652.) (Parte segunda de Varios, autigua, citada por Fajardo.) “, op. cit., p. 182. Sobre este dramaturgo, tal vez de ocasión, no conocemos, más "actuaciones literarias". En el Archivo de Palacio aparecen varios don Luis de Guzmán, contemporáneos a Cáncer. Adquiere un especial interés don Luis de Guzmán y Velasco, gentil hombre de Boca, en tiempos de Felipe III, según la documentación del expediente 495/8, pues aparece relacionado con acontecimientos importantes en la vida de Cáncer.

${ }_{23}$ Archivo de la Parroquia de San Sebastián, Lib. 9 Baut. fol. 255 v. Vid. M. Fernández García, Parroquia madrileña de San Sebastián, op. cit., p. 30. 


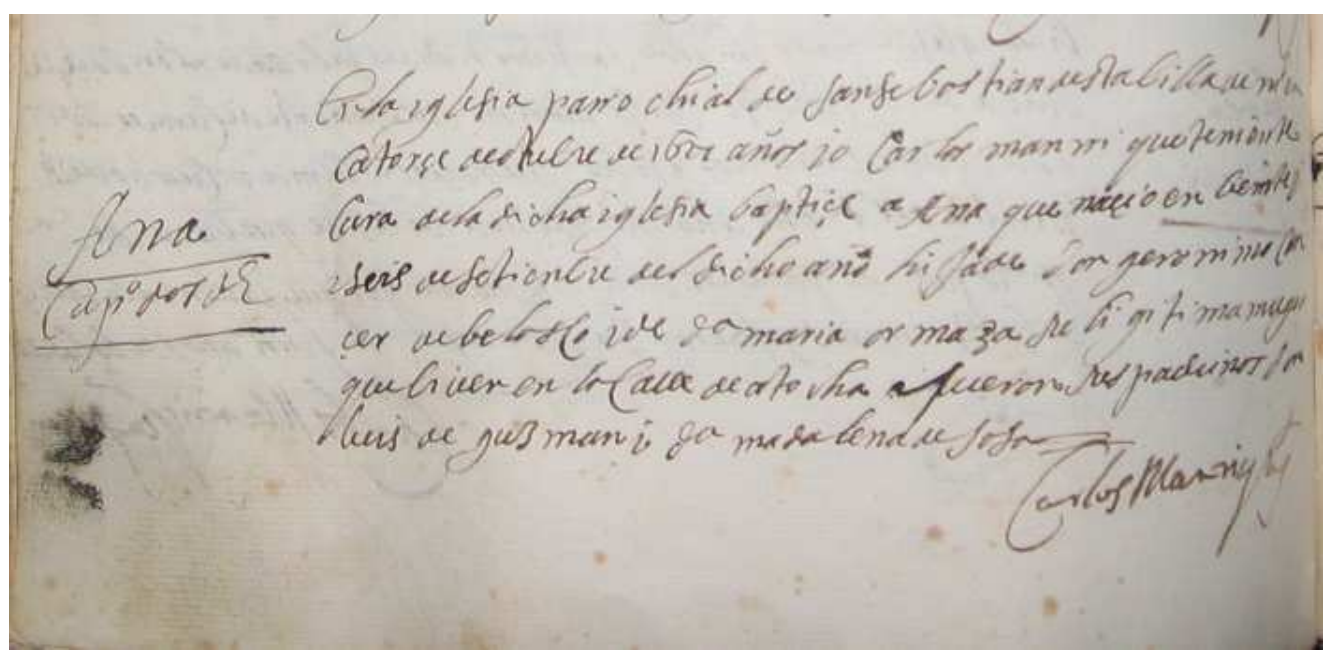

El tercer hijo no tardó en llegar, al año siguiente 1628. En septiembre llegó Antonio, pero Cáncer ha cambiado su domicilio a la calle Santa María, como lo señala el documento pertinente: "En la Iglesia Parroquial de San Sebastián de esta Villa de Madrid, en tres de octubre de 1628 años; yo, licenciado don Francisco de Corbalán, teniente cura de dicha Iglesia, bauticé a Antonio, que nació en catorce de septiembre del dicho año; hijo de don Jerónimo Cáncer y de doña María de Ormaza, su legítima mujer; que viven en la calle de Santa María; y fueron sus padrinos don Enrique de los Trillos y doña Maria de la Fuente Iboz Mediano. Firmado: Francisco de Corbalán"24.

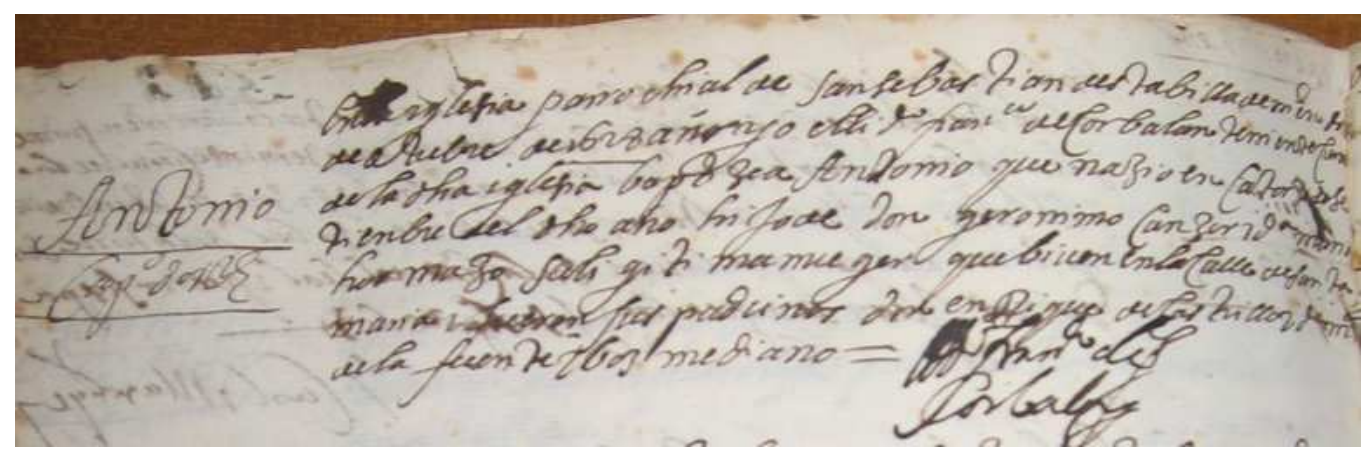

El cuarto hijo, Francisco, llegó a la nueva casa de Cáncer en la calle de Las Huertas en noviembre de 1629: "En la Iglesia Parroquial de San Sebastián de esta Villa de Madrid, en treinta de noviembre de 1628 años; yo, don

${ }^{24}$ Archivo de la Parroquia de San Sebastián, Lib. 9 Baut. Fol. 343v. Vid. M. Fernández García, Parroquia madrileña de San Sebastián, op. cit., p. 30. 
Francisco Corbalán, teniente cura de la dicha Iglesia, bauticé a Francisco, que nació seis de dicho mes y año, hijo de don Jerónimo Cáncer y de doña María de Ormaza, su legítima mujer; que viven en la calle de Las Huertas. Fueron sus padrinos don Gabriel Bravo y doña Margarita Bravo. Firmado Francisco Corbalán" 25 .

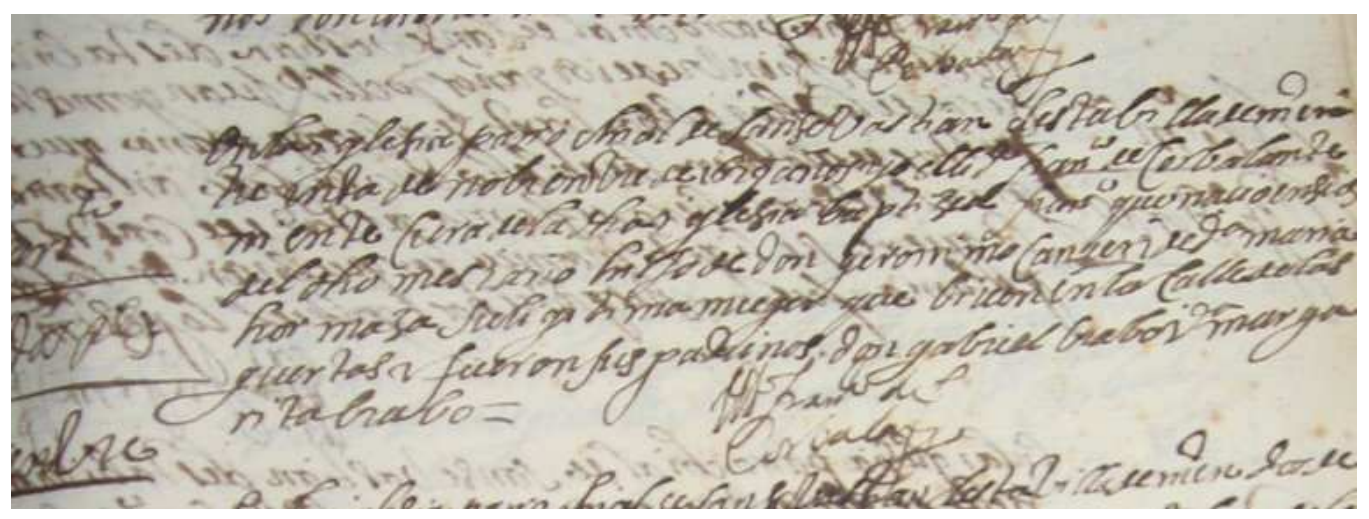

En 1631 -a finales de febrero- nace su hija María ${ }^{26}$. La familia continúa viviendo en la calle Las Huertas como puede leerse en la partida de bautismo: “En la Iglesia Parroquial de San Sebastián de esta Villa de Madrid en trece de Marzo de 1631. Yo Miguel Gálvez, bauticé a María que nació el veinticinco de febrero de dicho año, hija de de don Jerónimo Cáncer y de doña María de Ormaza, su legítima mujer; que viven en la calle de Las Huertas. Fueron sus padrinos don Simón Baez y Doña Catalina Ormaza"27.

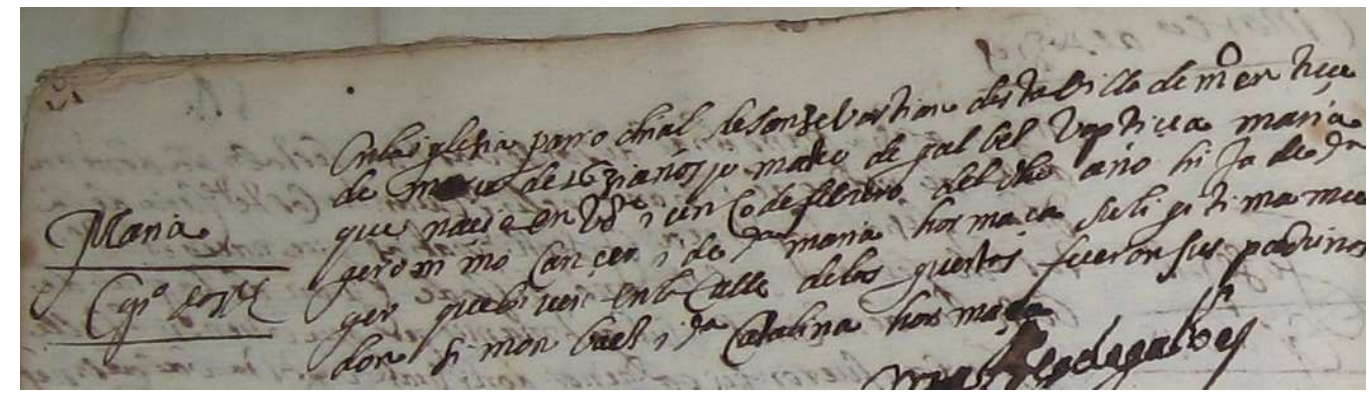

25 Archivo de la Parroquia de San Sebastián, Lib. 9 Baut. Fol. 428v. Vid. M. Fernández García, Parroquia madrileña de San Sebastián, op. cit., p. 30.

26 Archivo de la Parroquia de San Sebastián, Lib. 11 Dif. Fol. 149. Vid. M. Fernández García, Parroquia madrileña de San Sebastián, op. cit., p. 30.

27 Archivo de la Parroquia de San Sebastián, Lib. 10 Baut. Fol. 14v. Vid. M. Fernández García, Parroquia madrileña de San Sebastián, op. cit., p. 30. 
En la Parroquia de San Sebastián, Cáncer cristianizó a su hija Ana Bernardina, el día 6 de mayo de 1632: "En la Iglesia Parroquial de San Sebastián de esta Villa de Madrid, en seis de mayo de 1632 años; yo, licenciado don Francisco de Mata, dicha Iglesia, bauticé a Antonia Bernardina, hija de don Jerónimo Cáncer y Velasco y de doña María de Ormaza y Centella, su mujer legítima; que viven en la calle del Prado. Fueron sus padrinos don Bartolomé Febo y Petronila de Ormaza. Firmado Francisco de Mata"28.

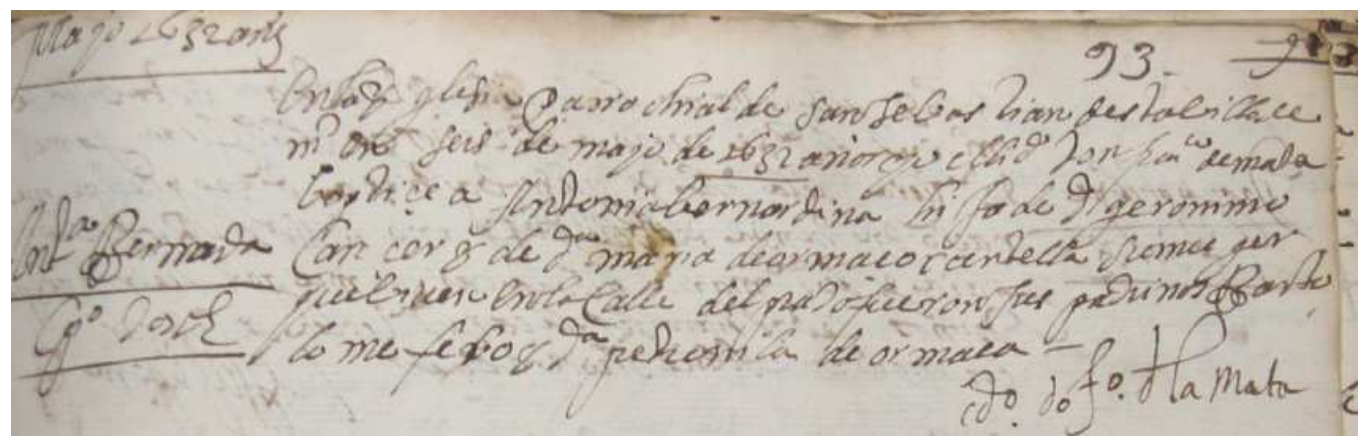

El último hijo del que tenemos noticias corresponde a Polonia, bautizada “En la Iglesia Parroquial de San Sebastián de esta Villa de Madrid, en veinte seis de febrero de 1634 años; yo, Jerónimo de Morales, bauticé a Polonia Cáncer, hija de don Jerónimo Cáncer y de doña María de Ormaza, su mujer; fueron sus padrinos don Juan Méndez Puebla y doña María de Guzmán. Firmado Jerónimo de Morales" 29 .

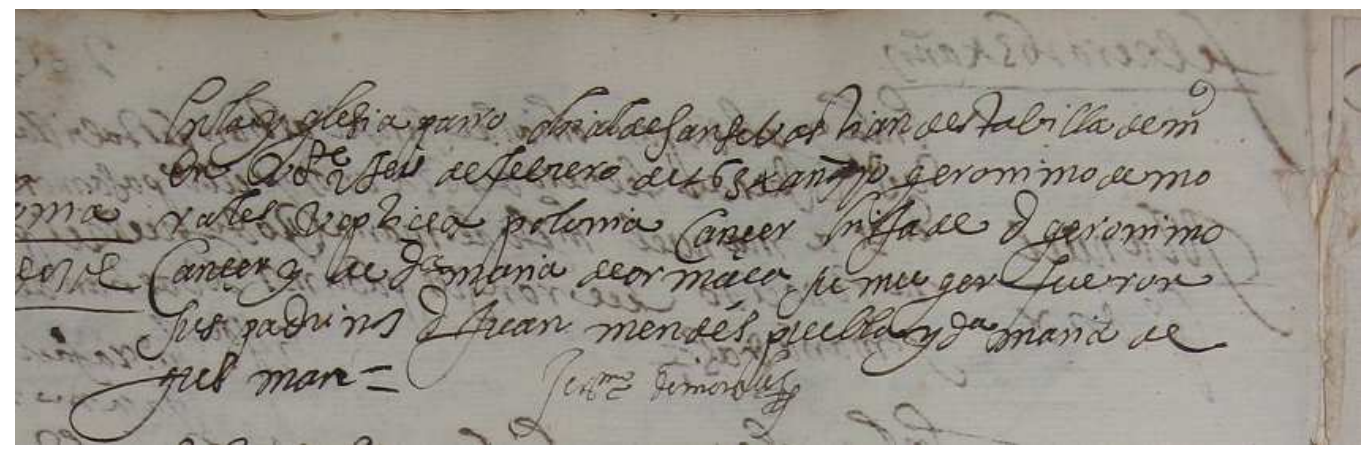

${ }^{28}$ Archivo de la Parroquia de San Sebastián, Lib. 10 Baut. Fol. 93r. Vid. M. Fernández García, Parroquia madrileña de San Sebastián, op. cit., p. 30.

29 Archivo de la Parroquia de San Sebastián, Lib. 10 Baut. Fol. 206v. Vid. M. Fernández García, Parroquia madrileña de San Sebastián, op. cit., p. 30. 
A pesar de los datos que aportamos -de indudable interés para futuras investigaciones, y que revelan la vida del poeta en la corte, sus viviendas y personas con las que convivió- quedan algunos enigmas todavía pendientes de dilucidar, como la suerte que tuvieron la mayoría de los hijos de Cáncer. Hasta la fecha no se han localizado sus partidas de matrimonio o defunción de ninguno de ellos y sólo sabemos -con certeza- que fue Antonia la única que vivía al morir su madre.

Al hilo de la malograda vida de los hijos de nuestro dramaturgo, es fácil recordar aquellos versos dedicados a un amigo y escritos, seguramente, en los últimos años del poeta.

Yo me recojo, en fin, casi de día, para que mi familia no me espere, que es la que vos sabéis, por dicha mía. Rezo y ceno tan poco, que, atrevido, suelo desafiar la poplegía.

Hasta acostarme, paso entretenido a mi hija celebrándole algún chiste, de mi mujer contado y añadido.

Solo el que aspira a holgarse, vive triste. No hay placer que a este gusto se le iguale, que en la quietud del ánimo consiste. ${ }^{30}$

La primera partida de defunción de la familia que se encuentra en el Archivo de San Sebastián, corresponde a nuestro dramaturgo, que falleció en Madrid en octubre de 1655 y que por su interés transcribimos íntegramente: “Don Jerónimo Cáncer, casado con Doña María Ormaza, calle de Las Huertas, frontero del Cementerio, murió en dos de octubre de 1655 años. Recibió los Santos Sacramentos. Testó ante Beltrán del Arce (?) en trece de diciembre de 1649 años. Dejo el funeral a voluntad de dicha mujer, enterrándose en las Trinitarias Calzadas. Dio a fábrica diez y seis reales" 31 .

\footnotetext{
30 «Carta a un amigo suyo, que le encargó que asistiese a una dama que había dejado en Madrid», Obras varias, vv. 101-111, p. 236.

31 Archivo de la Parroquia de San Sebastián, Lib. 10 Dif. Fol. 280. Vid. M. Fernández García, Parroquia madrileña de San Sebastián, op. cit., p. 30. No hemos encontrado hasta el momento el testamento de Cáncer en el Archivo de Protocolos de Madrid, ni escribano, ni similar, que se llame Beltrán del Arco o Arce.
} 


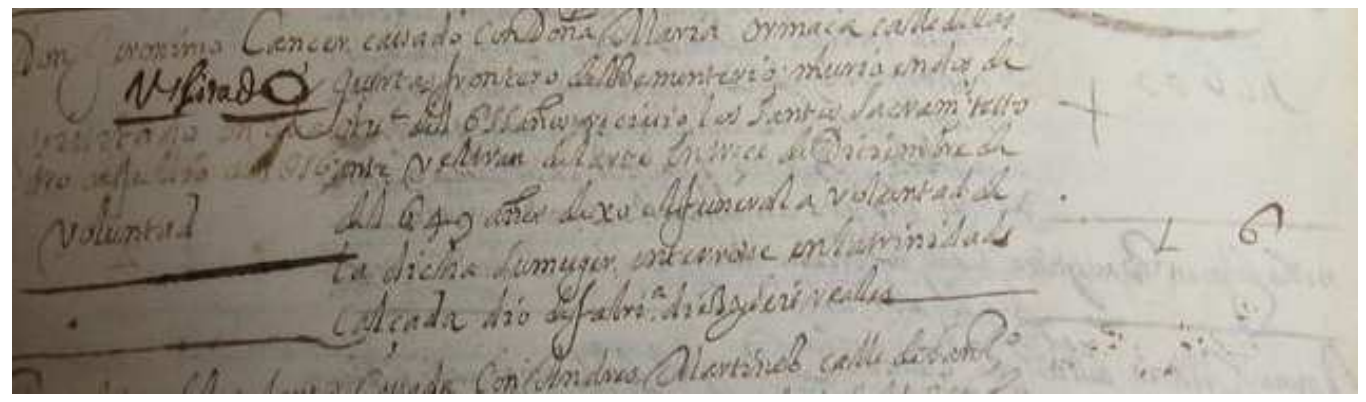

Cuatro años más tarde, en 1659, María Ormaza falleció en Madrid como lo recoge la partida de defunción que se conservan en el Archivo de La Parroquia de San Sebastián: "Doña María Ormaza, viuda de Jerónimo de Cáncer, calle de Santa Isabel, casas frontero a las de Miguel Espartal, murió veinte y cinco de noviembre de 1659 años. Recibió los Santos Sacramentos. Testó ante don Diego Ortiz de Mediana, el veinte y tres de noviembre de 1659 años. Dejó doscientas misas de alma. Testamentarios. Doña Ana Centeno calle Segunda de Leal, casas de Juan Villanueva. Enterrándose en la Trinidad. Dio a fabrica 16 reales" ${ }^{\prime 2}$.

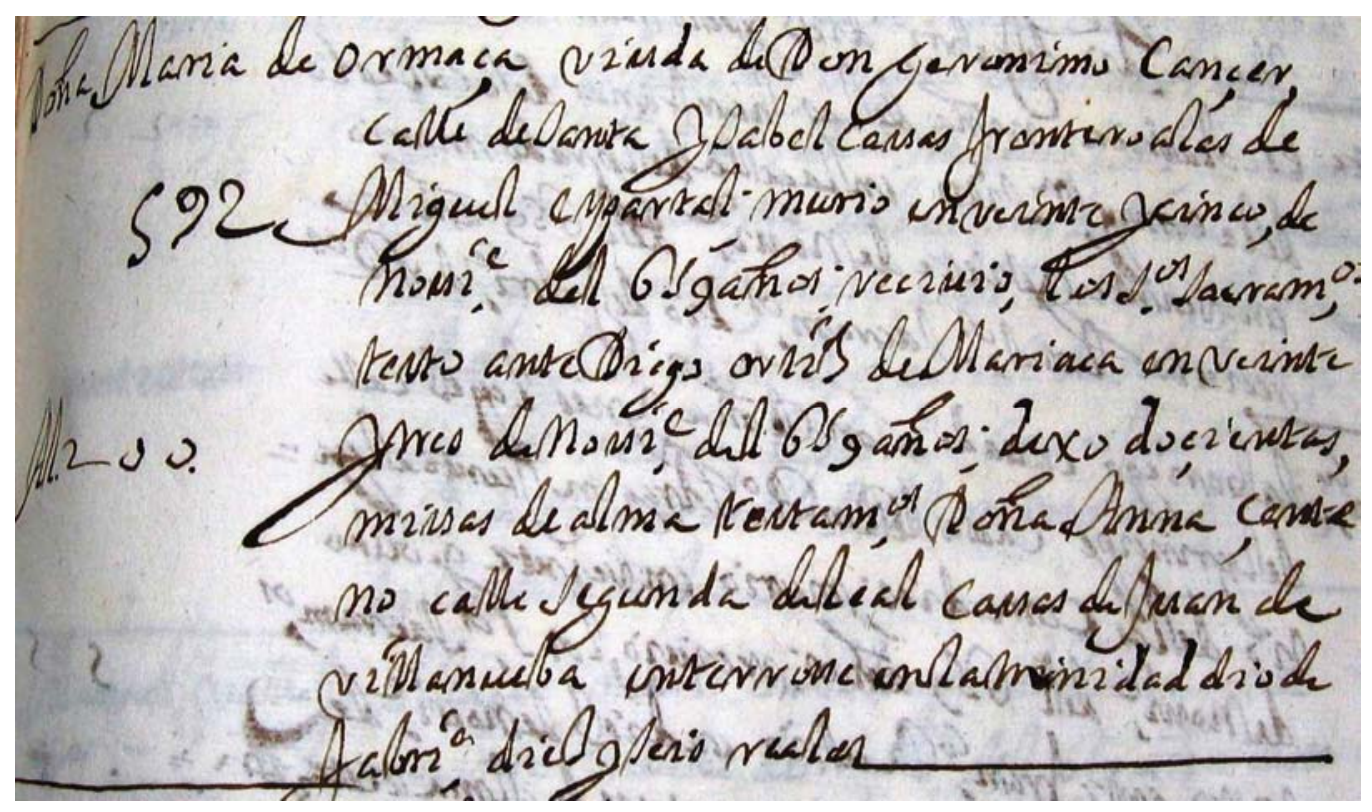

32 Archivo de la Parroquia de San Sebastián, Lib. 11 Dif. Fol. 149. Vid. M. Fernández García, Parroquia madrileña de San Sebastián, op. cit., p. 30. 
Gracias a la información de la partida de defunción de María Ormaza, nos fue posible encontrar su testamento ${ }^{33}$, que también incluímos, aunque no hemos hallado el de Cáncer. Con éste -el de su legítima mujer- cerramos una parte de la vida familiar del poeta y dramaturgo don Jerónimo de Cáncer y Velasco.

“In Dei nomine Amen. Sepan cuantos esta carta de testamento última y postrimera voluntad vieren como yo, Doña María Ormaza, viuda de D. Jerónimo Cáncer, vecina de esta villa, estando en la cama enferma de la enfermedad que Dios Nuestro Señor ha sido servido de darme, y en mi entero y lúcido y entendimiento natural, conociendo lo que veo y entendiendo lo que me dicen creyendo como bien verdaderamente creo en el Misterio de la Santísima Trinidad: Padre, Hijo y Espíritu Santo, tres personas distintas y un solo Dios verdadero, y en todo lo demás que tiene cree y confiesa la Santa Iglesia Romana, debajo de cuya fe y creencia protesto ${ }^{34}$ vivir y morir, y deseando poner mi alma en carrera de salvación invocando como invoco por mi intercesora y abogada a la Reina de los Ángeles, Nuestra Señora, para que alcance de su precioso Hijo perdón de mis culpas y pecados. Hago y ordeno este mi testamento en la forma y manera siguiente:

Primeramente, encomiendo mi alma a Dios Nuestro Señor que la crió y redimió con su preciosa sangre y el cuerpo mando a la tierra del que fue formado.

Mando que, cuando la voluntad de Dios Nuestro Señor fuere de llevarme de esta presente vida, mi cuerpo sea sepultado en la Iglesia Trinitarias Calzadas $^{35}$ de esta Villa ${ }^{36}$ y se me diga aquel día, si fuere hora, sino el siguiente, misa cantada de cuerpo presente con vigilia y responso sobre mi sepultura, y la disposición de mi entierro lo dejo a la de mi testamentaria a quien dejare nombrada.

Mando se digan por mi alma doscientas misas de indulgencias en altares privilegiados. Mando a las mandas forzosas y acostumbradas por los responsables repartidos entre todas con que las aporto del derecho que podrían tener a mis bienes.

Declaro, que Su Majestad (que Dios guarde), me hizo merced y a don Antonia Cáncer, mi hija legitima y del dicho Don Jerónimo Cáncer, mi marido, de doscientos ducados de renta. Durante nuestras vidas de mí y de la dicha

\footnotetext{
33 El testamento de María de Ormaza se encuentra en el Archivo de Protocolos de Madrid, en legajo 8590 , fol. 335r - 335v.

34 "Protesto": Confesar públicamente la fe y creencia que uno confiesa y en que desea vivir. Vid. DRAE.

35 Tachado: "parroquia de San Sebastián" y rectifica con "Trinitarios Calzados".

36 Tachado: "donde soy parroquiana".
} 
Doña Antonia, mi hija, situados en Penas de Cámara ${ }^{37}$ del Consejo de Indias, y de sus corridos se deben y están por pagar más de quinientos ducados. Es mi voluntad y se haga diligencia en su cobranza, y consiguiéndolo se me digan quinientas misas de indulgencia por mi alma y la del dicho Don Jerónimo, mi marido y por algunos cargos de obligación que tuviere de que no me acuerdo. $Y$ para cumplir y pagar este mi testamento y lo en él contenido.

Dejo y nombro por mi albacea y testamentaria a Doña Ana Centeno, mi madre, a quien doy mi poder cumplido cual le tengo, y para que entre en mis bienes y los venda y remate en pública almoneda o fuera de ella y de su valor cumpla y ejecute este testamento, y le dure este cargo todo tiempo necesario, aunque sea pasado el derecho concede y cumplido y pagado, o sea y en el remanente que quedare de todos mis bienes y muebles y raíces derechos y acciones. Instituyo por mi universal heredera en todos ellos a la dicha doña Antonia Cáncer, mi hija legítima y del dicho Don Jerónimo Cáncer mi marido, para que los halle y herede, con la bendición de Dios y de la mía. Y reboco y anulo, y doy por ningunos y de ningún valor, y efecto otros cuales quiere testamentos, codicillos, poderes para testar y otra cualquier disposición que antes de ahora pareciere haber hecho por escrito o de palabra o en otra manera que es mi voluntad no salgan, ni hagan efecto, ni fuera de él, salvo este que quiero se ejecute. Por mi testamento codicillo, última y final voluntad en aquella dicha y forma, que en derecho mejor lugar halla, en cuyo testimonio lo otorgo así ante el presente escribano, en la Villa de Madrid, a veintitrés días del mes de noviembre de mil seiscientos cincuenta y nueve años, siendo testigos llamados y rogados el licenciado Don Tomás Calcio, Martín Solana y Francisco Salgado residentes en Madrid y la otorgante. Yo, el escribano, doy fe, conozco. Dijo que por la gravedad de la enfermedad no podía firmar y a su ruego y lo firmo. Un testigo. Veintitrés Reales. Trinitarios Calzados. Parroquial San Sebastián. Donde soy parroquiana y también ya de ruego.

Ante mí

Francisco Salgado

Ortiz de Mediana

37 "Penas de cámara": las que se aplican por el fisco de del rey nuestro señor. Vid. S. de Covarrubias Orozco, Tesoro de la Lengua Castellana o Española, Madrid, Castalia, 1995, p. 242. 
Elena Martínez Carro y Alejandro Rubio San Román

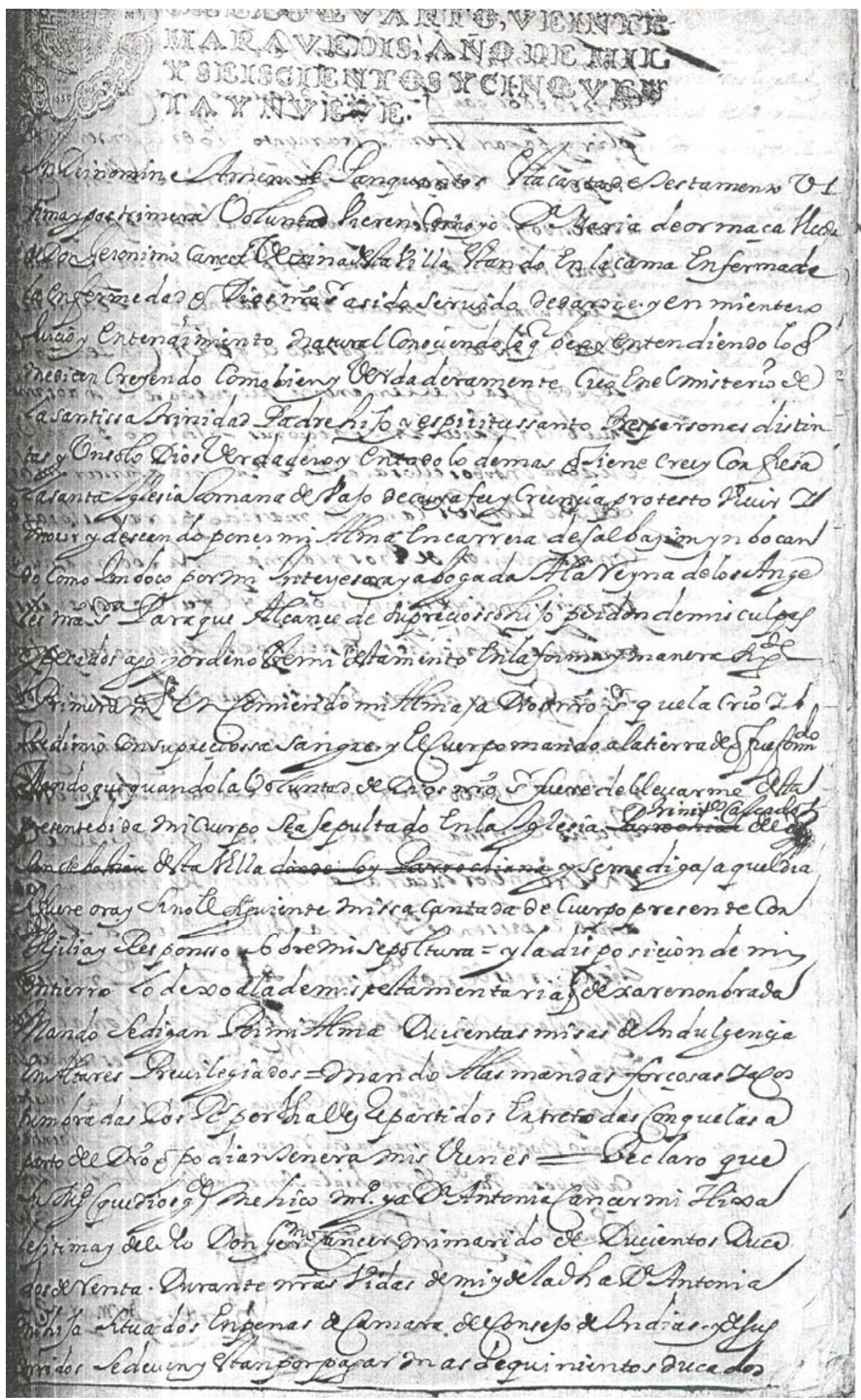


Documentos sobre Jerónimo de Cáncer y Velasco

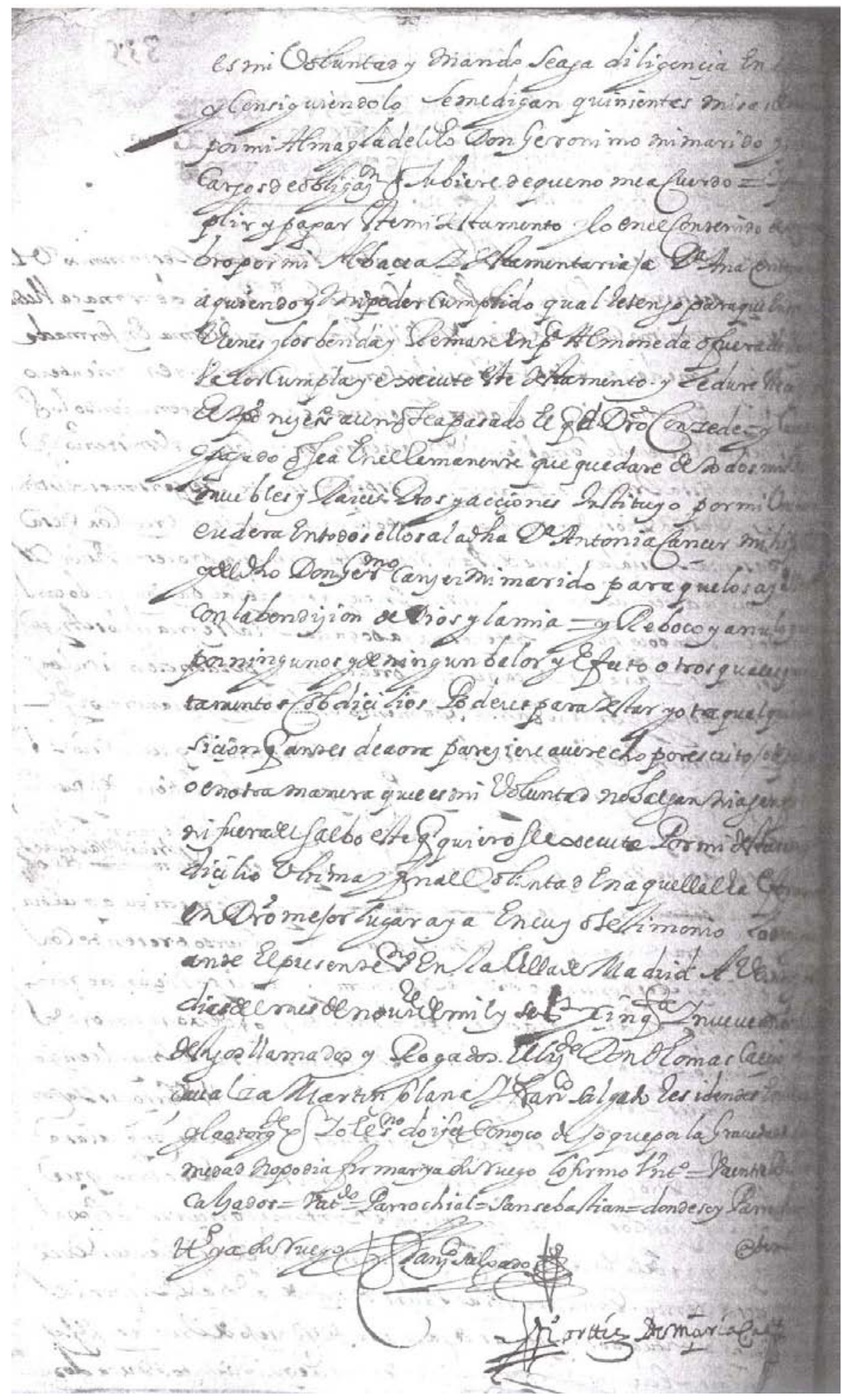

LECTURA Y SIGNO, 2 (2007) pp. 15-32 